\title{
Effect of the G72 (DAOA) putative risk haplotype on cognitive functions in healthy subjects
} Andreas Jansen*1, Sören Krach ${ }^{1}$, Axel Krug 6 , Valentin Markov², Thomas Eggermann ${ }^{3}$, Klaus Zerres ${ }^{3}$, Markus Thimm ${ }^{1}{ }^{12}$, Markus M Nöthen ${ }^{4}$, Jens Treutlein ${ }^{5}$, Marcella Rietschel ${ }^{5}$ and Tilo Kircher ${ }^{6}$

\author{
Address: ${ }^{1}$ Section of BrainImaging, Department of Psychiatry and Psychotherapy, Philipps-University Marburg, Germany, ${ }^{2}$ Department of \\ Psychiatry and Psychotherapy, RWTH Aachen University, Germany, ${ }^{3}$ Institute of Human Genetics, RWTH Aachen University, Germany, \\ ${ }^{4}$ Department of Genomics, Life \& Brain Center, University of Bonn, Germany, ${ }^{5}$ Division of Genetic Epidemiology in Psychiatry, Central Institute \\ of Mental Health, Germany and ${ }^{6}$ Department of Psychiatry and Psychotherapy, Philipps-University Marburg, Germany \\ Email: Andreas Jansen* - an.jan@gmx.de; Sören Krach - krachs@med.uni-marburg.de; Axel Krug - kruga@med.uni-marburg.de; \\ Valentin Markov - vmarkov@ukaachen.de; Thomas Eggermann - teggermann@ukaachen.de; Klaus Zerres - kzerres@ukaachen.de; \\ Markus Thimm - mthimm@ukaachen.de; Markus M Nöthen - markus.noethen@uni-bonn.de; Jens Treutlein - jens.treutlein@zi-mannheim.de; \\ Marcella Rietschel - marcella.rietschel@zi-mannheim.de; Tilo Kircher - kircher@med.uni-marburg.de \\ * Corresponding author
}

Published: 24 September 2009

BMC Psychiatry 2009, 9:60 doi:10.1 186/1471-244X-9-60
Received: 10 March 2009

Accepted: 24 September 2009

This article is available from: http://www.biomedcentral.com/I47I-244X/9/60

(C) 2009 Jansen et al; licensee BioMed Central Ltd.

This is an Open Access article distributed under the terms of the Creative Commons Attribution License (http://creativecommons.org/licenses/by/2.0), which permits unrestricted use, distribution, and reproduction in any medium, provided the original work is properly cited.

\begin{abstract}
Background: In the last years, several susceptibility genes for psychiatric disorders have been identified, among others $G 72$ (also named D-amino acid oxidase activator, DAOA). Typically, the high-risk variant of a vulnerability gene is associated with decreased cognitive functions already in healthy individuals. In a recent study however, a positive effect of the high-risk variant of $G 72$ on verbal working memory was reported. In the present study, we therefore examined the relationship between $G 72$ genotype status and a broad range of cognitive functions in 423 healthy individuals.
\end{abstract}

Methods: The $G 72$ carrier status was assessed by the two single nucleotide polymorphisms (SNPs) M23 and M24. Subjects were divided into three risk groups (low, intermediate and high risk).

Results: $G 72$ status influenced a number of cognitive functions, such as verbal working memory, attention, and, at a trend level, spatial working memory and executive functions. Interestingly, the high-risk allele carriers scored better than one or even both other groups.

Conclusion: Our data show that the putative high-risk haplotype (i.e. homozygote $\mathrm{C} / \mathrm{C}$-allele carriers in SNP M23 and homozygote T/T-allele carriers in SNP M24) is in healthy individuals not necessarily associated with worse performance in cognitive functions, but even with better performance in some domains. Further work is required to identify the mechanisms of $G 72$ on brain functions. 


\section{Background}

Cognitive functions are impaired in schizophrenia $[1,2]$ and, to a lesser extent, also in bipolar disorder $[3,4]$ and major depression [5]. Among the different cognitive domains, verbal memory, verbal fluency and attention are typically most affected $[2,3,5,6]$. Especially in schizophrenia, these impairments are already present in adolescence, long before the onset of psychotic symptoms $[4,6]$, in the prodromal state [7] and can also be found in relatives of patients $[8,9]$, suggesting a genetic influence.

In the last years, several susceptibility genes for psychiatric disorders have been identified (for reviews, see [10-13]. Among these, G72 (recently named D-amino acid oxidase activator, DAOA) is one of the most frequently replicated vulnerability genes [14]. It shows a genetic overlap across the major psychoses, such as bipolar disorder, major depression and schizophrenia [15-21], questioning the long-held view of a strict nosological separation of psychiatric disorders $[16,17]$.

To reveal potential in vivo functions of risk genes several studies have assessed genotype effects in healthy individuals. For several risk alleles, an association with subtle impairments in cognitive functions (e.g., [22]) or disadvantageous personality traits (e.g., $[21,23,24])$ have been found, although this does depend on the gene and the respective tagging marker.

In a recent study, we investigated the effect of G72 genotype on working memory using both neuropsychological tests and functional neuroimaging. Unexpectedly, the putative high-risk haplotype (i.e. homozygote $\mathrm{C} / \mathrm{C}$-allele carriers in the single nucleotide polymorphism (SNP)
M23 and homozygote T/T-allele carriers in SNP M24) was associated with significant better performance in verbal working memory. These behavioural differences were accompanied by a stronger deactivation in the right parahippocampus during a working memory 2-back task [25]. Thus, the high risk variant of $G 72$ has a beneficial influence on verbal working memory in healthy subjects, although it is known to increase the risk for schizophrenia and affective disorders, diseases that are associated with impairments in this domain $[2,3,5,6]$.

In the present study we further investigated how genetic alterations in G72 influence cognitive functions in healthy individuals. We examined whether the positive influence of the high risk G72 variant is restricted to verbal working memory or whether this genotype also beneficially influences other cognitive domains.

\section{Methods \\ Subjects}

The subjects were recruited through postings at the University of Aachen, advertisements in local newspapers and an e-mail sent to all students of the University of Aachen. 423 subjects ( 214 men, 209 women) were included in the present study. Inclusion criteria were age (18-55 years), right-handedness (as assessed by the Edinburgh Laterality Scale, [26]), no psychiatric disorders according to ICD-10 and Western- or Middle European descent. The subjects' characteristics are given in Table 1a.

After a complete description of the procedure subjects provided written informed consent to participate in the study. The protocol was approved by the local ethics committee according to the declaration of Helsinki. After par-

Table I: $\mathbf{G 7 2}$ risk status

\begin{tabular}{|c|c|c|c|c|c|}
\hline G72 risk status & low & intermediate & high & $\mathbf{F}$ & $\mathbf{p}$ \\
\hline \multicolumn{6}{|c|}{ a: Subjects' characteristics } \\
\hline number of subjects & 88 & 231 & 104 & & \\
\hline Sex ratio (men/women) & $43 / 45$ & $115 / 116$ & $56 / 48$ & $\chi^{2}=0.606$ & .739 \\
\hline Age (years) & $25.0(6.7)$ & $24.9(6.3)$ & $23.8(3.7)$ & 1.387 & .251 \\
\hline Education (years) & $15.5(2.6)$ & $15.5(2.8)$ & $15.5(2.2)$ & .005 & .995 \\
\hline \multicolumn{6}{|l|}{ b: Cognitive variables } \\
\hline Spatial span & $19.09(2.88)$ & $18.82(3.12)$ & $19.62(2.60)$ & 2.585 & .077 \\
\hline Letter-number-span test & $16.36(2.5 \mathrm{I})$ & $16.28(2.55)$ & $17.32(2.26)$ & 6.636 & $.001 *$ \\
\hline Trail Making Test & $58.29(15.01)$ & $62.85(19.67)$ & $57.31(15.42)$ & 4.357 & .013 \\
\hline Semantic verbal fluency & $30.75(8.88)$ & $30.91(9.21)$ & $32.81(9.63)$ & 1.734 & .178 \\
\hline Lexical verbal fluency & $17.38(4.25)$ & $16.54(4.47)$ & $16.89(5.08)$ & 1.096 & .335 \\
\hline d2-test & $201.3(35.7)$ & $188.0(33.5)$ & $198.8(33.8)$ & 6.545 & $.002 *$ \\
\hline
\end{tabular}

Subjects are divided into three groups (low, intermediate and high risk) according to their G72 status (based on two SNPs, M23 and M24). (a) Subjects' characteristics: sex, age and education. There were no significant group differences in sex ratio, age or education $(p>. I)$. (b) Cognitive results of a neuropsychological test battery testing working memory, executive functions, verbal fluency and attention. Due to Bonferroni corrections for multiple testing, a significance threshold of $p=0.008$ was set as significance criterion. Standard deviations are given in parentheses. Significant results are marked with '*'. 
ticipants provided consent, the cognitive tests were administered and blood was taken from a vein of each subject's arm.

\section{Genetic Analysis}

Subjects were genotyped as part of a sample described in Rietschel et al. [21] for two G72 SNPs (M23 = rs3918342 $[\mathrm{C} / \mathrm{T}]$ and $\mathrm{M} 24=$ rs 1421292 [T/A]) using the MassARRAY ${ }^{\circledast}$ system (Sequenom Inc., San Diego, Ca). For quality comparison purposes, we genotyped a subset of the sample in duplicate in order to estimate the replicate error rate. Two out of 96 DNA samples were randomly chosen for this purpose. For the SNPs genotyped, all genotypes between duplicates were consistent ( $0 \%$ replicate error rate). We also always include routinely positive and negative controls in our genotyping experiments. By a standard $1 \mathrm{df}$ chi-square test, there were no significant deviations from Hardy-Weinberg equilibrium for the genotype distributions of the studied sample.

The association between G72 genotype status and psychiatric disorders was obtained for different SNPs [14,27-29]. We chose the markers M23 and M24, because the M23M24 haplotypes C-T and T-A have recently been associated with schizophrenia, bipolar disorder, and major depression [21]. Depending on the M23 and M24 markers, the subjects were divided in three groups: low risk, intermediate risk and high risk. Subjects who had a homozygote T-allele on M23 and a homozygote A-allele on M24 were classified as "low risk". Subjects who had a homozygote C-allele on M23 and a homozygote T-allele on M24 were classified as "high risk". All other subjects belonged to the "intermediate risk" group.

In a post-hoc analysis, we additionally analysed all data separately for group classifications depending solely on the M23 and M24 status, respectively. The principal results did not change (see appendix and tables 2 and 3 ). This is not surprising, since both markers are highly correlated $(\mathrm{r}=0.94)$.

\section{Neuropsychological test battery}

We assessed working memory, executive functions, verbal fluency and attention. Working memory was measured with the spatial span of the Wechsler Memory Scale (spatial working memory, [30]) and with the letter-numberspan test (verbal working memory, [31]). Executive functions were assessed with the Trail Making Test (TMT-B, [32]). Verbal fluency was measured with semantic and lexical word generation [33]. Attention was assessed with the d2-test [34].

Behavioural data were analyzed using a univariate ANOVA design with G72 status (low, intermediate and high risk) as factor between subjects and outcome of the cognitive assessments as dependent variables. Bonferroni correction was applied to correct for multiple statistical testing (six tests, $\mathrm{p}=0.008$ ). In a post-hoc analysis, we additionally included age as covariate (since age is known to be significantly correlated with most of the dependent variables). The principal results however did not change.

\section{Results}

The ANOVA showed a significant $(\mathrm{p}<0.008)$ main effect of G72 status on verbal working memory ( $p=0.001$, the high risk group performed better than both other groups) and attention ( $\mathrm{p}=0.002$, the intermediate risk group performed worse than both other groups). Furthermore, there was a trend $(p<0.1)$ effect of G72 status on spatial working memory ( $p=0.077$, the high risk group performed better than both other groups) and executive function ( $p=0.013$, the intermediate risk group performed worse than both other groups) (Table 1b).

Table 2: Risk status calculated by $\mathrm{M} 23$

\begin{tabular}{|c|c|c|c|c|c|}
\hline G72 risk status (M23) & low & intermediate & high & $\mathbf{F}$ & $\mathbf{p}$ \\
\hline \multicolumn{6}{|c|}{ a: Subjects' characteristics } \\
\hline number of subjects & 95 & 221 & 107 & & \\
\hline Sex ratio (men/women) & $49 / 46$ & $108 / 113$ & $57 / 50$ & 0.607 & .738 \\
\hline Age (years) & $24.9(6.5)$ & $25.0(6.4)$ & $23.8(3.6)$ & 1.592 & .205 \\
\hline Education (years) & $15.6(2.6)$ & $15.5(2.8)$ & $15.5(2.2)$ & 0.068 & .935 \\
\hline \multicolumn{6}{|l|}{ b: Cognitive variables } \\
\hline Spatial span & $19.19(2.85)$ & $18.80(3.14)$ & $19.53(2.65)$ & 2.304 & .101 \\
\hline Letter-number-span test & $16.4 \mid(2.49)$ & $16.25(2.58)$ & $17.28(2.25)$ & 6.496 & .002 \\
\hline Trail Making Test & $58.41(14.62)$ & $62.81(19.95)$ & $57.73(15.39)$ & 3.804 & 0.23 \\
\hline Semantic verbal fluency & $30.76(8.72)$ & $31.00(9.31)$ & $32.57(9.61)$ & 1.277 & .280 \\
\hline Lexical verbal fluency & $17.25(4.27)$ & $16.57(4.48)$ & $16.87(5.05)$ & 0.753 & .472 \\
\hline d2-test & $200.9(35.0)$ & $187.6(33.4)$ & $198.8(34.3)$ & 6.832 & .001 \\
\hline
\end{tabular}


Table 3: Risk status calculated by M24:

\begin{tabular}{|c|c|c|c|c|c|}
\hline G72 risk status (M24) & low & intermediate & high & $\mathbf{F}$ & $\mathbf{p}$ \\
\hline \multicolumn{6}{|c|}{ a: Subjects' characteristics } \\
\hline number of subjects & 88 & 220 & 115 & & \\
\hline Sex ratio (men/women) & $43 / 45$ & $109 / 111$ & $62 / 53$ & 0.709 & .702 \\
\hline Age (years) & $25.0(6.7)$ & $24.8(6.2)$ & $24.1(4.4)$ & 0.718 & .489 \\
\hline Education (years) & $15.5(2.6)$ & $15.5(2.9)$ & $15.6(2.2)$ & 0.010 & .990 \\
\hline \multicolumn{6}{|l|}{ b: Cognitive variables } \\
\hline Spatial span & $19.09(2.88)$ & $18.84(3.15)$ & $19.50(2.62)$ & 1.900 & .151 \\
\hline Letter-number-span test & $16.36(2.52)$ & $16.23(2.55)$ & $17.31(2.28)$ & 7.600 & .001 \\
\hline Trail Making Test & $58.29(15.00)$ & $62.84(19.50)$ & $57.85(16.34)$ & 3.845 & .022 \\
\hline Semantic verbal fluency & $30.75(8.88)$ & $30.86(9.22)$ & $32.72(9.56)$ & 1.754 & .174 \\
\hline Lexical verbal fluency & $17.38(4.25)$ & I $6.47(4.53)$ & $16.98(4.90)$ & 1.348 & .261 \\
\hline d2-test & $201.3(35.7)$ & $187.7(33.7)$ & $198.4(33.4)$ & 6.663 & .001 \\
\hline
\end{tabular}

\section{Discussion}

In the present study we investigated the effect of G72 genotype on cognitive functions in a large sample of healthy individuals. Our results show that G72 status influences the performance in a number of cognitive domains (significant differences in verbal working memory and attention, differences on a trend level in spatial working memory and executive functions). Most importantly, the high-risk allele carriers scored significantly better than one or even both other low-risk groups. Thus, healthy individuals with a G72 haplotype that is known to increase the risk for the major psychoses perform better in some cognitive domains than subjects with a low risk status, although these cognitive domains are negatively affected by the psychiatric disorders that are associated with this allele variant.

Only few studies assessed so far the effect of genetic variation in G72 on cognitive functions. Goldberg et al. investigated the relationship between several SNPs in the G72 region and select cognitive measures in attention, working memory, and episodic memory in a cohort of over 600 subjects, including patients with schizophrenia, their unaffected siblings, and healthy controls. The authors showed for the markers M23 and M24 a significant genotype by diagnosis interaction with a number of cognitive measures (working memory, attention, verbal learning). The low risk homozygote A/A genotype group scored better than the high risk T/T homozygote group, most notably in the schizophrenia group [35]. Although the authors also report a main effect of genotype at least for marker $\mathrm{M} 24$, this effect seems to be mainly driven by the patient sample. Opgen-Rhein and colleagues investigated the influence of $G 72$ variation on cognitive performance in a large sample of both patients schizophrenia $(\mathrm{n}=178)$ and healthy controls $(n=144)$ [36]. They showed that a certain G72 haplotype located upstream of the presumed gene borders of G72 has an impact on semantic fluency.
Interestingly, carriers of the risk haplotype showed better semantic fluency than non-carriers, both in the patients and the control population. Donohue and colleagues report that a functional polymorphism within G72 (rs 2391191, M15) was associated with poorer verbal memory performance among patients with schizophrenia [37]. Taken together, these studies show that functional polymorphisms in the G72 gene region have an impact on cognitive functions. This impact seems to be most notable in psychiatric samples. Our study further extends these previous findings and show that the SNPs in the G72 gene complex have also an impact on cognitive functions in healthy controls.

Our results suggest that, at least for markers M23 and M24, the high-risk genotype of G72 has no negative effect on cognitive functions in healthy individuals per se, but even a positive effect in some cognitive domains (such as verbal working memory and attention). This finding is at first glance counterintuitive, but might be explained by a number of reasons. First, the M23-M24 risk haplotype might influence cognitive functions independent of its role as a risk factor for psychiatric disorders. A similar explanation has been proposed by Opgen-Rhine and colleagues who also report that a risk haplotype in the G72 region is associated with better performance in semantic processing both in patients with schizophrenia and control subjects [36]. Second, from a standpoint of evolutionary theory, it might be argued that the risk variant of G72 is maintained in the population since it has a beneficial influence on cognitive functions which has a positive effect for evolutionary selection [36]. At last, it cannot be fully excluded that at least some of the results represent false positive findings. It is for instance in particular difficult to understand why the intermediate risk group has a significant worse performance in the d2-test in comparison to both the high- and the low-risk group. A limitation of our study is that we cannot give a stringent neurobio- 
logical explanation for these findings. However, all results are based on a large cohort ( $\mathrm{n}=423)$, were obtained by stringent statistical analyses and survived Bonferroni corrected thresholds, reducing the likelihood of this interpretation.

The functional mechanisms of G72 are still not fully understood. Chumakov and colleagues showed that the G72 protein (which is only known in higher primates) activates a second protein, D-amino acid oxidase (DAAO), that is involved in the mechanisms of D-serine [38]. D-serine is an agonist at the glycine modulation site of the N-methyl-D-aspartate (NMDA) receptor [39]. Thus, G72 might work as an indirect modulator of NMDA neurotransmission, which has been implicated in various cognitive domains. Lower serum level of D-serine has been shown, for instance, in patients with schizophrenia. Furthermore, the administration of D-serine (as add-on medication) has been shown to reduce some of the symptoms in schizophrenia [40]. This provides a potential link between $G 72$ and the glutamate hypofunction hypothesis of schizophrenia [41]. Another study however failed to confirm the interaction between G72 and DAAO [42]. Rather, LG72, a splicing isoform of the G72 gene, encodes for a mitrochondrial protein. It was shown that an overexpression of G72 led to mitrochondrial fragmentation. The authors proposed that an unknown function of the G72 in modulating mitochondrial morphology might be responsible for the risk-conferring property of the gene.

Several fMRI studies suggest a modulatory role of G72 on brain activity in the medial temporal lobe (MTL), in particular the hippocampus and parahippocampus $[25,35,43]$. Goldberg and colleagues showed that healthy control subjects carrying the homozygous high-risk $\mathrm{T} / \mathrm{T}$ allele at SNP M24 had decreased brain activity of the right hippocampus and left parahippocampus during an episodic memory encoding task [35]. Hall et al. investigated subjects with a high familial risk for schizophrenia and report brain activation differences related to the G72 genotype (as assessed by SNPs M23 and M24) in the left hippocampus and parahippocampus during a verbal sentence completion task [43]. Jansen and colleagues showed that in healthy control subjects the G72 genotype (determined by SNPs M23 and M24) is correlated with brain activity of the right parahippocampus during a working memory task [25].

\section{Conclusion}

Taken together, these findings can be summarized as follows:

1. G72 is a vulnerability gene for several psychiatric disorders, including schizophrenia, bipolar disorder, major depression, and panic disorder [14]. However, about $25 \%$ of the general population, as suggested by the present study, carry the high-risk-variant, making a direct negative effect of the "high-risk" haplotype of G72 unlikely.

2. The high-risk variant increases the risk for cognitive impairments in patients with schizophrenia, that is, when the disorder is already in an acute state [35]. However, the high-risk haplotype does not negatively affect cognitive abilities per se, but has a beneficial influence on some cognitive functions in healthy individuals (as shown in the present study). This might be one reason, why the allele has not been selected out during evolution.

3. Functional imaging studies suggest a modulatory influence of G72 on brain activity in the MTL (hippocampus, parahippocampus) $[25,35,43]$. These structures are involved in the pathogenesis of affective disorders and particularly schizophrenia $[44,45]$.

The mechanism of G72 might therefore be explained by the following hypothesis:

G72 has a modulatory influence on brain activity in the MTL. The high-risk variant has overall a positive effect on cognitive abilities, but also increases the risk, in combination with other (unknown) genetic and epigenetic factors, to increase the risk for psychiatric disorders via its modulatory influence on the MTL structures.

\section{Competing interests}

The authors declare that they have no competing interests.

\section{Authors' contributions}

AJ performed the statistical analysis, was involved in the interpretation of data, made substantial contributions to conception and design and drafted the manuscript. SK was involved in the statistical analysis and the interpretation of data and helped to draft the manuscript. AK was involved in the acquisition of data, made substantial contributions to conception and design and was involved in drafting the manuscript. VM was involved in the acquisition of data and was involved in drafting the manuscript. MT was involved in the statistical analysis and the interpretation of data and helped to draft the manuscript. TE was involved in the genetic analyses and was involved in drafting the manuscript. $\mathrm{KZ}$ was involved in the genetic analyses and was involved in drafting the manuscript. $\mathrm{MN}$ made substantial contributions to conception and design, was involved in the genetic analyses. JT was involved in the genetic analyses and was involved in drafting the manuscript. MR made substantial contributions to conception and design and was involved in the genetic analyses. TK conceived of the study, and participated in its design and 
coordination and helped to draft the manuscript. All authors read and approved the final manuscript.

\section{Appendix}

In a post-hoc analysis, we additionally analysed all data separately for group classifications depending solely on the M23 and M24 status, respectively. The principal results did not change. This is not surprising, since both markers are highly correlated $(r=0.94)$. In this appendix, we additionally present the results of these analyses. See tables 2 and 3.

\section{Acknowledgements}

This work was supported by the Federal Ministry of Education and Research (FKZ 0IGO0204 and 0I GW075I). We are grateful to Jane Horn and Anna Weiß for help in the data collection process.

\section{References}

I. Glahn DC, Almasy L, Blangero J, Burk GM, Estrada J, Peralta JM, Meyenberg N, Castro MP, Barrett J, Nicolini H, Raventos H, Escamilla MA: Adjudicating neurocognitive endophenotypes for schizophrenia. Am J Med Genet B Neuropsychiatr Genet 2007, I44B:242-249.

2. Heinrichs RW, Zakzanis KK: Neurocognitive deficit in schizophrenia: a quantitative review of the evidence. Neuropsychology 1998, 12:426-445.

3. Quraishi S, Frangou S: Neuropsychology of bipolar disorder: a review. J Affect Disord 2002, 72:209-226.

4. Tiihonen J, Haukka J, Henriksson M, Cannon M, Kieseppa T, Laaksonen I, Sinivuo J, Lonnqvist J: Premorbid intellectual functioning in bipolar disorder and schizophrenia: results from a cohort study of male conscripts. Am J Psychiatry 2005, 162:1904-1910.

5. Zakzanis KK, Leach L, Kaplan E: On the nature and pattern of neurocognitive function in major depressive disorder. Neuropsychiatry Neuropsychol Behav Neurol 1998, I I: I I I-I I 9.

6. Reichenberg A, Weiser M, Rabinowitz J, Caspi A, Schmeidler J, Mark M, Kaplan Z, Davidson M: A population-based cohort study of premorbid intellectual, language, and behavioral functioning in patients with schizophrenia, schizoaffective disorder, and nonpsychotic bipolar disorder. Am J Psychiatry 2002, 159:2027-2035

7. Simon AE, Cattapan-Ludewig K, Zmilacher S, Arbach D, Gruber K, Dvorsky DN, Roth B, Isler E, Zimmer A, Umbricht D: Cognitive functioning in the schizophrenia prodrome. Schizophr Bull 2007, 33:76I-77I.

8. Barrantes-Vidal N, Aguilera M, Campanera S, Fatjo-Vilas M, Guitart M, Miret S, Valero S, Fananas L: Working memory in siblings of schizophrenia patients. Schizophr Res 2007, 95:70-75.

9. Ma X, Wang O, Sham PC, Liu X, Rabe-Hesketh S, Sun X, Hu J, Meng H, Chen W, Chen EY, Deng W, Chan RC, Murray RM, Collier DA, Li $T$ : Neurocognitive deficits in first-episode schizophrenic patients and their first-degree relatives. Am J Med Genet B Neuropsychiatr Genet 2007, I44B:407-4I6.

10. Harrison PJ, Weinberger DR: Schizophrenia genes, gene expression, and neuropathology: on the matter of their convergence. Mol Psychiatry 2005, 10:40-68.

II. Owen M], Craddock N: O'Donovan MC, Schizophrenia: genes at last? Trends Genet 2005, 21:518-525.

12. Smoller JW, Gardner-Schuster E: Genetics of bipolar disorder. Curr Psychiatry Rep 2007, 9:504-5II.

13. Chubb JE, Bradshaw NJ, Soares DC, Porteous DJ, Millar JK: The DISC locus in psychiatric illness. Mol Psychiatry 2008, 13:36-64.

14. Detera-Wadleigh SD, McMahon FJ: G72/G30 in schizophrenia and bipolar disorder: review and meta-analysis. Biol Psychiatry 2006, 60:106-114

15. Craddock N, O'Donovan MC, Owen MJ: The genetics of schizophrenia and bipolar disorder: dissecting psychosis. J Med Genet 2005, 42:193-204.
16. Craddock N, O'Donovan MC, Owen MJ: Genes for schizophrenia and bipolar disorder? Implications for psychiatric nosology. Schizophr Bull 2006, 32:9-16.

17. Craddock N, Owen MJ: The beginning of the end for the Kraepelinian dichotomy. Br J Psychiatry 2005, 186:364-366.

18. Green EK, Raybould R, Macgregor S, Gordon-Smith K, Heron J, Hyde S, Grozeva D, Hamshere M, Williams N, Owen MJ, O'Donovan MC, Jones L, Jones I, Kirov G, Craddock N: Operation of the schizophrenia susceptibility gene, neuregulin I, across traditional diagnostic boundaries to increase risk for bipolar disorder. Arch Gen Psychiatry 2005, 62:642-648.

19. Williams NM, Green EK, Macgregor S, Dwyer S, Norton N, Williams H, Raybould R, Grozeva D, Hamshere M, Zammit S, Jones L, Cardno A, Kirov G, Jones I, O'Donovan MC, Owen MJ, Craddock N: Variation at the DAOA/G30 locus influences susceptibility to major mood episodes but not psychosis in schizophrenia and bipolar disorder. Arch Gen Psychiatry 2006, 63:366-373.

20. Maier W, Hofgen B, Zobel A, Rietschel M: Genetic models of schizophrenia and bipolar disorder: overlapping inheritance or discrete genotypes? Eur Arch Psychiatry Clin Neurosci 2005, 255:159-166.

21. Rietschel M, Beckmann L, Strohmaier J, Georgi A, Karpushova A, Schirmbeck F, Boesshenz KV, Schmal C, Burger C, Jamra RA, Schumacher J, Hofels S, Kumsta R, Entringer S, Krug A, Markov V, Maier W, Propping P, Wust S, Kircher T, Nothen MM, Cichon S, Schulze TG: G72 and Its Association With Major Depression and Neuroticism in Large Population-Based Groups From Germany. Am J Psychiatry 2008, 165:753-762.

22. Egan MF, Goldberg TE, Kolachana BS, Callicott JH, Mazzanti CM, Straub RE, Goldman D, Weinberger DR: Effect of COMT Val I 08/ 158 Met genotype on frontal lobe function and risk for schizophrenia. Proc Natl Acad Sci USA 200I, 98:6917-6922.

23. Krug A, Markov V, Leube D, Zerres K, Eggermann T, Nothen MM, Skowronek MH, Rietschel M, Kircher T: Genetic variation in the schizophrenia-risk gene neuregulin I correlates with personality traits in healthy individuals. Eur Psychiatry 2008, 23:344-349.

24. Sheldrick A, Krug A, Markov V, Leube D, Michel TM, Zerres K, Eggermann T, Kircher T: Effect of COMT val ${ }^{158}$ met Genotype on Cognition and Personality. Eur Psychiatry 2008, 23:385-389.

25. Jansen A, Krach S, Krug A, Markov V, Eggermann T, Zerres K, Stocker T, Shah NJ: Nothen MM, Treutlein J, Rietschel M, Kircher T, A putative high-risk haplotype of the $\mathbf{G 7 2}$ gene is associated with better performance in working memory functions in healthy individuals: A combined neuropsychological and functional imaging study. Neuroimage 2009, 45:1002-1008.

26. Oldfield RC: The assessment and analysis of handedness: the Edinburgh inventory. Neuropsychologia |97।, 9:97-II3

27. Shi J, Badner JA, Gershon ES, Liu C: Allelic association of G72/G30 with schizophrenia and bipolar disorder: a comprehensive meta-analysis. Schizophr Res 2008, 98:89-97.

28. $L i D, H e$ L: G72/G30 genes and schizophrenia: a systematic meta-analysis of association studies. Genetics 2007, 175:917-922.

29. Abou JR, Schmael C, Cichon S, Rietschel M, Schumacher J, Nothen MM: The G72/G30 gene locus in psychiatric disorders: a challenge to diagnostic boundaries? Schizophr Bull 2006, 32:599-608.

30. Wechsler D: Wechsler Memory Scale: Administration and Scoring Manual. The Psychological Corporation: Harcourt Brace \& Co, San Antonio TX; 1997

31. Gold JM, Carpenter C, Randolph C, Goldberg TE, Weinberger DR: Auditory working memory and Wisconsin Card Sorting Test performance in schizophrenia. Arch Gen Psychiatry 1997, 54:159-165.

32. Reitan RM, Wolfson D: The Halstead-Reitan neuropsychological test battery: Theory and clinical interpretation. Neuropsychology Press, Tuscon; 1985.

33. Lezak M: Neuropsychological Assessment. Oxford University Press, Oxford; 1995.

34. Brickenkamp R: Der Aufmerksamkeits-Belastungstest d2. Hogrefe, Göttingen; 2002.

35. Goldberg TE, Straub RE, Callicott JH, Hariri A, Mattay VS, Bigelow L, Coppola R, Egan MF, Weinberger DR: The G72/G30 gene complex and cognitive abnormalities in schizophrenia. Neuropsychopharmacology 2006, 31:2022-2032. 
36. Opgen-Rhine $C$, Lencz $T$, Burdick KE, Neuhaus $A H$, DeRosse $P$ Goldberg TE, Malhotra AK: Genetic variation in the DAOA gene complex: Impact on susceptibility for schizophrenia and on cognitive performance. Schizophr Res 2008, I03:169-I77.

37. Donohue G, Morris DW, Robertson IH, McGhee KA, Murphy K, Kenny N, Clarke S, Gill M, Corvin AP: DAOA ARG30LYS and verbal memory function in schizophrenia. Mol Psychiatry 2007, $0: 1-2$.

38. Chumakov I, Blumenfeld M, Guerassimenko O, Cavarec L, Palicio M Abderrahim H, Bougueleret L, Barry C, Tanaka H, La RP, Puech A, Tahri N, Cohen-Akenine A, Delabrosse S, Lissarrague S, Picard FP, Maurice K, Essioux L, Millasseau P, Grel P, Debailleul V, Simon AM, Caterina D, Dufaure I, Malekzadeh K, Belova M, Luan JJ, Bouillot M, Sambucy JL, Primas G, Saumier M, Boubkiri N, Martin-Saumier S, Nasroune M, Peixoto H, Delaye A, Pinchot V, Bastucci M, Guillou S, Chevillon M, Sainz-Fuertes R, Meguenni S, urich-Costa J, Cherif D, Gimalac A, Van DC, Gauvreau D, Ouellette G, Fortier I, Raelson J, Sherbatich T, Riazanskaia N, Rogaev E, Raeymaekers P, Aerssens ], Konings F, Luyten W, Macciardi F, Sham PC, Straub RE, Weinberger DR, Cohen N, Cohen D: Genetic and physiological data implicating the new human gene $\mathbf{G 7 2}$ and the gene for D-amino acid oxidase in schizophrenia. Proc Natl Acad Sci USA 2002, 99:13675-13680

39. Ohi K, Hashimoto R, Yasuda Y, Yoshida T, Takahashi T, like N, Fukumoto M, Takamura H, Iwase M, Kamino K, Ishii R, Kazui H, Sekiyama R, Kitamura Y, Azechi M, Ikezawa K, Kurimoto R, Kamagata E, Tanimukai H, Tagami S, Morihara T, Ogasawara M, Okochi M, Tokunaga $H$, Numata S, lkeda M, Ohnuma T, Ueno S, Fukunaga T, Tanaka T, Kudo T, Arai H, Ohmori T, Iwata N, Ozaki N, Takeda M: Association study of the G72 gene with schizophrenia in a Japanese population: a multicenter study. Schizophr Res 2009, 109:80-85

40. Boks MP, Rietkerk T, Beek MH van de, Sommer IE, de Koning T] Kahn RS: Reviewing the role of the genes G72 and DAAO in glutamate neurotransmission in schizophrenia. Eur Neuropsychopharmacol 2007, 7:567-572.

41. Coyle JT: Glutamate and schizophrenia: beyond the dopamine hypothesis. Cell Mol Neurobiol 2006, 26:365-384

42. Kvajo M, Dhilla A, Swor DE, Karayiórgou M, Gogos JA: Evidence implicating the candidate schizophrenia/bipolar disorder susceptibility gene $\mathbf{G 7 2}$ in mitochondrail function. Mol Psychiatry 2008, 13:685-696.

43. Hall J, Whalley HC, Moorhead TW, Baig BJ, Mclntosh AM, Job DE, Owens DG, Lawrie SM, Johnstone EC: Genetic Variation in the DAOA (G72) Gene Modulates Hippocampal Function in Subjects at High Risk of Schizophrenia. Biol Psychiatry 2008 , 64:428-433

44. Harrison PJ: The hippocampus in schizophrenia: a review of the neuropathological evidence and its pathophysiological implications. Psychopharmacology (Berl) 2004, 174:151-162.

45. Heckers S: Neuroimaging studies of the hippocampus in schizophrenia. Hippocampus 200I, I I:520-528.

\section{Pre-publication history}

The pre-publication history for this paper can be accessed here:

http://www.biomedcentral.com/1471-244X/9/60/pre pub

\section{Publish with Bio Med Central and every scientist can read your work free of charge}

"BioMed Central will be the most significant development for disseminating the results of biomedical research in our lifetime. "

Sir Paul Nurse, Cancer Research UK

Your research papers will be:

- available free of charge to the entire biomedical community

- peer reviewed and published immediately upon acceptance

- cited in PubMed and archived on PubMed Central

- yours - you keep the copyright
BioMedcentral 